Volume 9, No.1.4, 2020

International Journal of Advanced Trends in Computer Science and Engineering

Available Online at http://www.warse.org/IJATCSE/static/pdf/file/ijatcse5991.42020.pdf

https://doi.org/10.30534/ijatcse/2020/5991.42020

\title{
Social Media Use in Higher Education: Exploring Activities for Learning
}

\author{
Nur Shamsiah Abdul Rahman ${ }^{1}$, Waleed Al-Rahmi ${ }^{2}$, Muhaini Othman ${ }^{3}$ \\ ${ }^{1}$ Faculty of Computing, Universiti Malaysia Pahang, 25150 Kuantan, Pahang, Malaysia, shamsiah@ump.edu.my \\ ${ }^{2}$ Faculty of Education, Universiti Teknologi Malaysia, 81310 Skudai, Johor, Malaysia. \\ waleed.alrahmi@yahoo.com \\ ${ }^{3}$ Faculty of Computer Science and Information Technology, Universiti Tun Hussein Onn Malaysia, Parit Raja, \\ 86400, Malaysia. muhaini@uthm.edu.my
}

\begin{abstract}
In recent years, social media is used frequently in daily life. Hence, some of the university students have been motivated by the recent popularity of social media technologies in using them for learning activities. Still there is few of research that has been conducted to justify clearly the process how the social media tools are useful for the learning activities for teaching and learning. There are 235 undergraduate students in Faculty of Computing, Universiti Teknologi Malaysia (UTM) took part in this study. Thus, the adoption process of learning activities has been explained by the employment of the structural equation modeling (SEM) technique with the SmartPLS program. The general structural model was developed and this includes the social media use, learning activities, content generating, communicate for sharing, discussion for learning, and teaching and learning. In this study, the results have shown that all the factors are positively and significantly related to learning activities and consequently could affect the teaching and learning in developing active learning.
\end{abstract}

Key words: Learning activities, social media technologies, higher education, structural equation modeling.

\section{INTRODUCTION}

Social media technologies have developed and grown boundlessly especially in higher education. In these recent years, there have been many reviews and debates regarding practices of social media especially in higher education and the trends can be recognized in most of the higher education institutions in all over the world [1, 2, 3, 4, 5]. In developing and maintaining the social contacts and relationships while supporting the informal learning practices and learning activities, the students are actively using the social media to sustain their academics in education [6].

In the comparison with the traditional learning, most of the social media tools are more adaptable and compliant to advocate student-centered learning environment, engage the students in joining the common interest groups together, assist each other in academic studies, create strong relationship with their classmates and encourage supplementary collaboration between them and their instructors [7, 8]. Social media tools also act as a groundwork for students' engagement and collaboration by creating a platform for meaningful discussion $[9,10]$. Despite the use social media has big potential for the students and educators themselves, the researchers have debated about the possible advantages, factors, threats and demanding that should be reviewed. Thus, the future research is needed to explore the usage of social media technologies for the purposes of learning together with the effects to the teaching and learning [11].

Millions of contemporary Malaysian students use social media every day, however, little is known how they use and the implications of the use social media to them [12]. Therefore, this paper seeks to address the usage of social media technologies by students, sheds new light on the learning activities that directly can give effect to the teaching and learning process. Based on the literature reviews, we have addressed a conceptual framework and presupposed that the teaching and learning is positively influenced by the learning activities. This paper organized as follows. First section gives a brief discussion on literature review. The second section is presented the research model and hypothesis. Section four gives a brief overview of research methodology. Next section analyses the result obtained and our conclusions are drawn in the final section.

\section{LITERATURE REVIEW}

In the higher education in all over the places in this world, the online social media activities are the most frequently used. The previous researchers have attracted to examine and verify in determining the ways of those tools could be used for teaching and learning because of the development use of social media in educational environment. The rationale behind using social media tools in teaching and learning because social media tools provides a platform for generation $\mathrm{Y}$ students to socially interact, communicate and discuss about their learning with their classmates [13]. 
There were many previous studies that have explored the impacts of social media use in the effectiveness of teaching and learning in general $[14,15,16]$. Ventura and Quero [17] claimed that using social media in aiding teaching and learning of Economics and Business Studies helped improve the students' set of competences. Weisberger in Educational-Portal has stated that there may be more pedagogical beneficial in an active use of social media. This hypothesis is supported by research by Junco et al. [19] and Blaschke et al. [20] which suggested that an active use of social media may enhance the learner engagement levels (student-student, student-instructor and student content). Besides, it can stimulate the establishment of cognitive and meta-cognitive learning skills, for example like reflection, critical thinking, construction of knowledge and understanding of one's individual learning process.

The teaching and learning among the students in higher institution is really affected by the significant role of social media [21]. There are many specialized services that have been equipped by the social media tools in education, which include the social networking sites, blogs, media sharing and social bookmarking. Both lecturers and students in the higher education attain lots of pedagogical benefits through these social media tools [22]. In this case, the social media tools are actually indirectly assisted the sharing of resources, ideas and thoughts, publications, writings and notes [23]. In addition, most of the students in higher education may talk about any topic to be discussed with the external community and they can also have or produce different thoughts by those sharing resources and materials provided [24].

The social technologies that is publicly available for social media have been provided appropriately for learning activities in the higher education sector [25]. Stand on a comprehensive literature review, there are three categories of social media activities that we have specified, which are communication for sharing, discussion for learning and content generating [26]. The interactions among students are positively sustained by the social media tools as they manage to let the students to contribute and communicate actively in a discussion. After reading the blog or discussion board, they can write comments to give respond or request for more details explanation. Most social media tools allow students to actively share information and express their opinions and easily create their own content.

Despite the fact that the use of social media tools can give many benefits to students in learning purposes has been claimed by the most researchers, there are still not adequate studies which can hold up these statements. Meyer [27] has indicated that there is lack of empirical studies regarding the impact of social media use in higher education. Several attempts need to have been made to the existing literature on the educational benefits of using social media tools. To enlighten these issues, this study has conducted to analyze the learning activities using social media which support teaching and learning among the students. The results obtained in this research will really assist us to get the understanding and develop our use of social media tools in educational contexts, in order to let us adapt and adopt our teaching strategies and methods so that it is in parallel with the education needs to a better future.

\section{RESEARCH FRAMEWORK AND HYPOTHESES}

The recent study merges the significant factors which including the social media use, learning activities, communicate for learning, discussion for learning, content generation, and teaching and learning into a single model that can be evaluated and validated the integration of social media aspects that was never conducted in prior studies. Figure 1 depicts the research framework in this study.

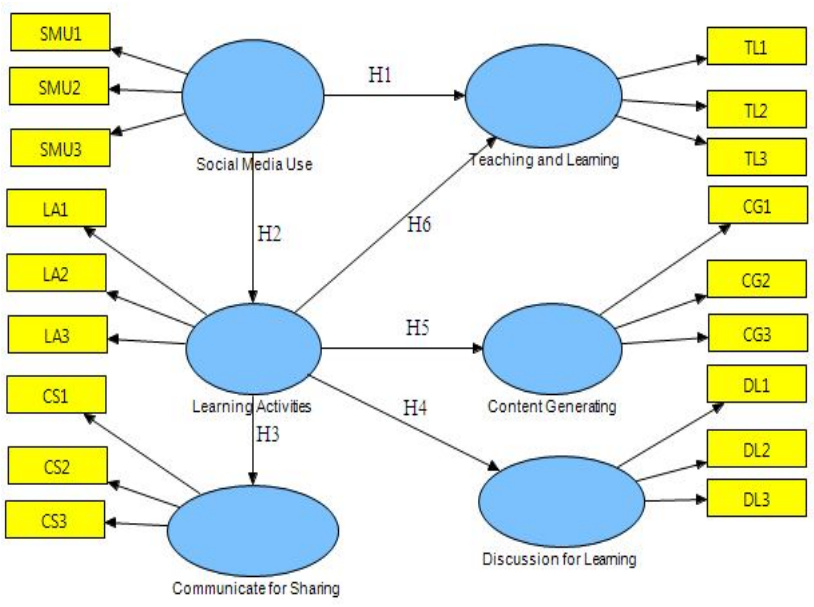

Figure 1: Research Framework

\subsection{Social Media Use}

Since their introduction social media tools have gained a large number of followers especially among the youths and also university students. As the development of technologies around the world, it is not surprising that the social media tools become dominant and important materials as they manage to help teaching and learning. There are many advantages of social media use that have been discovered by the present literature especially in educational purposes. Those social media tools manage to promote flexibility of process in teaching and learning and they also help for the easy publication, sharing thoughts and have the ability to improving student's interaction [28], offering personalized course materials $[8,29]$ and enhancing learning motivation and experience [30, 31]. The past researcher also considered that social media may act as a capable teaching material in higher education as it can be used conveniently [32].

\subsection{Learning Activities}

Today, most of the times in daily life are spent on social media. Studies showed that social media tools have become a medium in having a range of applications that really helpful and they have been associated with the learning activities 
used in the university level. They manage to assist the students in the interaction making, communication, critical thinking and active participation [37, 38]. Awodele et al. [39] have discovered that the level of contribution, communication and collaboration between students and lecturers have been enhanced through the use of social media especially for learning purposes. Similar studies by Hamid et al. [26] stated that the regular educational activities for both students and lecturers can be completely implemented by using the social media tools included but are to restrict to the content generating, interacting, sharing, and collaboratively socializing. Mazman and Usluel [40] revealed relationship between educational usage with communication, collaboration and material and sharing using Facebook equally have influenced positively to the respondents. Learning activities through media social also can enrich the students' contribution in the classroom, especially for the introvert students. Previous studies reported that anxiety levels among students can be reduce by using social media tools, as it may lower the voice in asking questions to them rather than front of their friends [41, 42].

\subsection{Communicate for Sharing}

Social media tools interactivity features make it different from the traditional learning management system. Hence, students consider that they have been provided a dependable means of interaction through the social media tools. The students can share their ideas on the public space. Currently, Padlet, SlideShare, Flickr and YouTube allow sharing the multimedia files. The content and information that have been shared by using the social technologies can be used more than just to publish them online. We manage to get improvement and enrichment on the sharing content and information. In addition, the contents might be expanded by someone else as they may put more facts and figures or correct mistakes in data like on Wikipedia. The EDUCAUSE Centre for Analysis and Research survey found that students want to use social media to communicate and sharing about learning information with peers and instructors [50]. Students described instructors using social media to facilitate communication about course related matters outside of class. One student specifically stated that it is "very helpful" to have their instructor active on a class Facebook page. Another student reported using Facebook to form a closed group to share information and discuss course related matters. Research indicates that students use social media to contact their instructors, as well as to share information about co-curricular activities and academic resources with classmates [9].

\subsection{Discussion for Learning}

Tasir et al. [38] in their previous research discovered that students believed that they can freely make and contribute in a group discussion through media tools. This finding is similar with Coffin and Fournier [50] and Hollyhead et al. [51] where their study found that the University of Washington's students preferred to use social media as their medium for discussion compared to course LMS discussion board and majorities preferred to make a discussion about their learning using student-made Facebook groups. Majority of high school students are online participating in discussions and groups to observe content and disseminate information. Social media tools are seen making its way into the educational environment when their applications have even more potential to improve learning and sharing information among student.

\subsection{Content Generating}

The social media technologies let the users to preferably make their own content including sharing the information, ideas and thoughts among the network of users actively. Through the content generating activities, social media technologies allow let the students to enhance their knowledge and associate them with their learning community. By doing this kind of activity, the students may write entries in the blog to generate more ideas in their work and assignments to public $[47,49,53]$. Content generating let the students to contribute actively and creatively in making multimedia content for publishing on file sharing like YouTube [43, 49].

\subsection{Teaching and Learning}

There are many opinions and thought that have been discussed on the use of social media for teaching and learning $[53,54,55]$. It is widely believed that social media tools have the technological and educational capabilities to support teaching and learning [56]. The past researchers have stated that the social media technologies assist constructivist approaches to learning and have possibilities in enhancing the communication in online learning to a bigger extent rather than in the previous learning environment $[10,57]$. In addition, past researchers considered that the social media can act as a potential teaching material in higher education as it can be used conveniently, ready availability, and individual affordability and network effects [32]. From the lecturers' perspective, by using the social media in teaching and learning can help in developing the online discussion among the students even they are outside of the classroom. Some of the technologies of social media like wikis and blog are manageable in collaborative activities amongst students for the production of course assignments. This allows for active participation and therefore effective learning by students [59]. From the students' perspective, they want to use social media as a platform for discussion compared to course LMS discussion board and students want to use social media to communicate with peers and lecturers [50]. Students described lecturers using social media to facilitate communication about course related matters outside of class. Another student reported using Facebook to form a closed group to share information and discuss course related matters. Research indicates that students use social media to contact their instructors, as well as to share information about 
co-curricular activities and academic resources with classmates [9]. Therefore, it concludes that the social media use in teaching and learning for higher education manages in developing the teaching and learning skills and practices of both lecturers and students. Based on the above discussion, the research hypotheses examined in this work are as follows: H1: There's a significant relationship between social media use and teaching and learning.

H2: There's a significant relationship between social media use and learning activities.

H3: There's a significant relationship between learning activities and communicate for sharing.

H4: There's a significant relationship between learning activities and discussion for learning.

H5: There's a significant relationship between learning activities and content generating.

H6: There's a significant relationship between learning activities and teaching and learning.

\section{RESEARCH METHODOLOGY}

In this study, there are 235 questionnaires that have been collected. The sample were randomly selected among undergraduate students at Faculty of Computing, Universiti Teknologi Malaysia. Statistical significance was analyzed by using SPSS and SmartPLS application. The instrument was developed based on research objectives, and after piloted, the value for Cronbach's alpha reliability and validity was found to be 0.849 . Such validity is acceptable and thus, the instrument was deemed to satisfy the reliability requirement. Also, a Likert scale of five points with 1 depicting strongly disagree and 5 depicting strongly agree was employed in this study. The questionnaire was refined according to the results of the pilot study conducted among students. A total of 18 items comprised in the questionnaire.

\section{RESULT AND DISCUSSION}

Table 1 shows the demographic information of survey respondents including their gender, nationality, age, department, network size on social media, frequency of social media usage, experience use of social media and hours spend online daily. In total 235 undergraduates' students take part in this study. The result shows the predominance of female students $(65.1 \%)$ over the male students $(34.9 \%)$. Out of the 235 respondents, only $1.7 \%$ ( $\mathrm{f}=4$ ) is non-Malaysian, while the rest are Malaysian $(\mathrm{f}=231)$. The analysis indicates the most of the respondents were at the age of 21-22 years old (52.3\%), $30.6 \%$ were at the age of 23-24 years old. This is followed by the age of $19-20$ years old $(9.4 \%)$, whereas $5.5 \%$ and $2.1 \%$ were at the age of 25-26 years old and 17-18 years old respectively. According to this distribution, $52.3 \%(\mathrm{f}=123)$ of the students studying at the Department of Information System, $34.0 \% \quad(\mathrm{f}=80)$ at the Department of Software Engineering, $8.5 \%(\mathrm{f}=20)$ at the Department of Computer Graphics and Multimedia, 3.0\% ( $\mathrm{f}=7$ ) at the Computers
System and Communication and $2.1 \% \quad(\mathrm{f}=5)$ at the Department of Industrial Computing and Modeling. A majority of the respondents have a large network size. From the analysis, $57.4 \%$ ( $\mathrm{f}=135$ ) have more than 500 friends, followed by $36.2 \%(\mathrm{f}=85$ ) have $300-500$ friends and $3.8 \%$ $(\mathrm{f}=9)$ have 200-300 friends. Only $0.9 \% \quad(\mathrm{f}=2)$ of the respondents have less than 10 friends in their favorite social media list. From the data analysis, the result also shows that the majority of the respondents constantly logged on their favorite account $(89.8 \%)$, meanwhile $7.2 \%(\mathrm{f}=17$ ) use several times a day, $2.1 \%(\mathrm{f}=5)$ use only once in a few days and $0.9 \%$ $(\mathrm{f}=2)$ use only once in a week. The data collected also shows almost all of the respondents have more than 3 years' experience in social media. Only $0.9 \%(\mathrm{f}=2)$ have less than one-year experience. Finally, the analysis results show that the majority of the respondents $(94.0 \%)$ have spent 1-4 hours per day, followed by $5.1 \%(\mathrm{f}=12)$ spent $5-8$ hours and $0.9 \%$ (f=2) spent 9-12 hours.

\subsection{Measurement and Instrumentation}

Partial Least Square Structural Equation Modelling (PLS-SEM), Smart PLS 2.0 was used to confirming the validity and the reliability of the measurement model. Before the hypotheses are tested, two steps were conducted to establish the model's goodness-of-fit namely construct validity and convergence validity. Construct validity test included loading and cross-loading of the items. Convergence validity test included the determination of factor loadings, composite reliability, R-Square, and Cronbach's alpha. According to [60], the criterion test should be used to confirm discriminant validity. The tests are discussed in the following sub-sections in detail.

Table 1: Demographic profiles and descriptive statistics of respondents

\begin{tabular}{cccc}
\hline Measure & Items & Frequency & $\%$ \\
\hline Gender & Male & 82 & 34. \\
& Female & 153 & 65. \\
& & & 1 \\
Age & $17-18$ & 5 & 2.1 \\
& $19-20$ & 22 & 9.4 \\
& $21-22$ & 123 & 52. \\
& $23-24$ & 72 & 3 \\
& $25-26$ & 13 & 30. \\
& & & 6 \\
Nationality & Malaysian & 231 & 5.5 \\
& & & 3 \\
Department & Others & 4 & 1.7 \\
& Information System & 123 & 52. \\
& Software Engineering & 80 & 3 \\
& & & 34. \\
& Computer Graphics \& & 20 & 8.5 \\
& Multimedia & & \\
& Industrial Computing \& & 5 & 2.1 \\
& Modeling & & \\
& Computer Systems \& & 7 & 3.0 \\
& Communication & & \\
& Less than 10 friends & 2 & 0.9 \\
& 10-100 friends & 0 & 0.0 \\
\hline \multirow{5}{*}{ Network size } & & &
\end{tabular}


Nur Shamsiah Abdul Rahman et al., International Journal of Advanced Trends in Computer Science and Engineering, 9(1.4), 2020,413 - 422

\begin{tabular}{cccc} 
& $100-200$ friends & 4 & 1.7 \\
& $200-300$ friends & 9 & 3.8 \\
& $300-500$ friends & 85 & 36. \\
& & & 2 \\
& More than 500 friends & 135 & 57. \\
& & 4 \\
Experience use & Less than one year & 2 & 0.9 \\
& $1-2$ years & 0 & 0.0 \\
& $2-3$ years & 0 & 0.0 \\
Frequency of social & More than 3 years & 233 & 99. \\
media usage & I am constantly logged on & 211 & 89. \\
& & & 8 \\
& Several times a day & 17 & 7.2 \\
Once in a few days & 5 & 2.1 \\
Hours spend online & Once a week & 2 & 0.9 \\
daily & Less than once a week & 0 & 0.0 \\
& $1-4$ hours & 221 & 94. \\
& & & 0 \\
& $5-8$ hours & 12 & 5.1 \\
& $9-12$ hours & 2 & 0.9 \\
& 13 hours and above & 0 & 0.0 \\
\hline
\end{tabular}

\subsection{Construct Validity of the Measurements}

Construct validity refers to the degree of the developed items can suitably measure what it claims and align with the concept that are intended to measure [61]. This measurement is important to ensure the entire measures developed able to measure a construct to load higher on their construct compared to other constructs. In the classical model of test validity, construct validity is one of three main types of validity evidence, alongside content validity and criterion validity.

This was guaranteed through a thorough literature review of prior studies to identify items that whose reliability has already been established and tested. On the basis of the results of factor analysis, all items were appropriately assigned to their constructs as they revealed high loadings to their respective constructs in comparison to other constructs (See Table 2) according to the criterion proposed by [62].

Table 2: Loading and cross-loadings of the items

\begin{tabular}{|c|c|c|c|c|c|c|c|}
\hline Variables & Code & SMU & LA & CS & $\mathrm{DL}$ & CG & TL \\
\hline \multirow{6}{*}{$\begin{array}{l}\text { Social Media } \\
\text { Use }\end{array}$} & SMU1 & 0.57 & 0.51 & 0.41 & 0.31 & 0.48 & 0.50 \\
\hline & & 7 & 2 & 5 & 1 & 0 & 6 \\
\hline & SMU2 & 0.71 & 0.45 & 0.55 & 0.41 & 0.39 & 0.49 \\
\hline & & 5 & 2 & 5 & 7 & 8 & 0 \\
\hline & SMU3 & 0.82 & 0.71 & 0.60 & 0.59 & 0.48 & 0.80 \\
\hline & & 1 & 0 & 5 & 9 & 7 & 8 \\
\hline \multirow{6}{*}{$\begin{array}{l}\text { Learning } \\
\text { Activities }\end{array}$} & LA1 & 0.40 & 0.78 & 0.50 & 0.40 & 0.42 & 0.70 \\
\hline & & 1 & 3 & 0 & 7 & 1 & 2 \\
\hline & LA2 & 0.57 & 0.66 & 0.61 & 0.57 & 0.49 & 0.55 \\
\hline & & 7 & 8 & 0 & 8 & 9 & 9 \\
\hline & LA3 & 0.67 & 0.81 & 0.66 & 0.70 & 0.54 & 0.52 \\
\hline & & 5 & 9 & 6 & 1 & 2 & 2 \\
\hline \multirow{6}{*}{$\begin{array}{l}\text { Communicate } \\
\text { for Sharing }\end{array}$} & CS1 & 0.71 & 0.60 & 0.88 & 0.70 & 0.60 & 0.69 \\
\hline & & 8 & 4 & 4 & 7 & 0 & 8 \\
\hline & $\mathrm{CS} 2$ & 0.81 & 0.70 & 0.91 & 0.86 & 0.72 & 0.56 \\
\hline & & 7 & 9 & 6 & 5 & 1 & 9 \\
\hline & CS3 & 0.87 & 0.57 & 0.89 & 0.83 & 0.87 & 0.53 \\
\hline & & 9 & 3 & 8 & 1 & 3 & 2 \\
\hline \multirow{6}{*}{$\begin{array}{l}\text { Discussion for } \\
\text { Learning }\end{array}$} & DL1 & 0.76 & 0.80 & 0.74 & 0.82 & 0.64 & 0.79 \\
\hline & & 1 & 2 & 0 & 2 & 4 & 2 \\
\hline & DL2 & 0.82 & 0.78 & 0.62 & 0.87 & 0.71 & 0.59 \\
\hline & & 0 & 8 & 5 & 6 & 2 & 0 \\
\hline & DL3 & 0.61 & 0.63 & 0.52 & 0.72 & 0.61 & 0.60 \\
\hline & & 1 & 0 & 1 & 4 & 9 & 3 \\
\hline Content & CG1 & 0.55 & 0.42 & 0.71 & 0.80 & 0.83 & 0.49 \\
\hline Generating & & 2 & 8 & 9 & 1 & 2 & 9 \\
\hline
\end{tabular}

\begin{tabular}{cccccccc} 
& CG2 & 0.60 & 0.51 & 0.59 & 0.61 & $\mathbf{0 . 7 4}$ & 0.70 \\
& & 1 & 3 & 8 & 0 & $\mathbf{2}$ & 0 \\
& CG3 & 0.70 & 0.60 & 0.50 & 0.77 & $\mathbf{0 . 8 2}$ & 0.61 \\
& & 2 & 3 & 9 & 7 & $\mathbf{3}$ & 8 \\
& TL1 & 0.48 & 0.70 & 0.81 & 0.60 & 0.82 & $\mathbf{0 . 9 1}$ \\
Teaching and & & 8 & 2 & 4 & 7 & 1 & $\mathbf{4}$ \\
Learning & & 0.63 & 0.71 & 0.59 & 0.71 & 0.60 & $\mathbf{0 . 9 1}$ \\
& & 5 & 4 & 5 & 9 & 0 & $\mathbf{6}$ \\
& TL3 & 0.58 & 0.64 & 0.70 & 0.61 & 0.83 & $\mathbf{0 . 9 2}$ \\
& & 8 & 1 & 1 & 7 & 2 & $\mathbf{6}$ \\
\hline
\end{tabular}

\subsection{Convergent Validity of the Measurements}

Convergence validity refers to how closely the new scale is related to other variables and other measures of the same construct [60]. This provides evidence that our theory that all four items are related to the same construct is supported. For the calculation of convergence validity, factor loadings were used. Table 3 outlines the value of factor loadings and it shown that all loadings of the items were from $0.701-0.903$ which are exceeded the recommended threshold (0.70). Meanwhile, Cronbach's alpha values differs from 0.713 to 0.917 exceeding the recommended value of 0.70 . The value of average variance extracted (AVE) also differ from 0.547-0.704, which is exceeded the suggested minimum threshold value of 0.50 . In addition to that, Smart PLS combines a factor analysis with near regressions, makes only minimal assumptions, with the goal of variance explanation high R-square [61]. The entire factor loadings are significant and exceeded 0.50 indicating that the recommendations provided by $[59,61]$ were satisfied. Table 3 also displays the CFA results for the measurement model.

\subsection{Discriminant Validity of the Measurements}

Discriminant validity is a test that assesses the level to which a concept and its indicators vary from one concept to the next [63]. The discriminant validity is achieved when the square root of the construct's AVE exceeds the inter-correlation between each construct and the rest of the constructs. Table 4 depicts that the results of each indicator item and it shows that all the AVE values exceeded the 0.50 recommended value with $p=0.001$. From the results shown, it is found that the criteria of discriminant validity are adequate and indicates that the discriminant validity is supported for the entire constructs [60].

\subsection{Analysis of the Structural Model}

Following the establishment of the measurement model's goodness of fit, the next phase involved the testing of the hypothesized relationships among the constructs and this is carried out through Smart PLS 2.0, specifically through the PLS algorithm. In this test, the path coefficients were produced as displayed in Figures 1 based on the illustrations in Figures 2, 3 and Table 3 and 4.

As seen in Table 5, all the hypotheses were supported. Based on the analysis, it shows that social media use is influenced directly by teaching and learning at $(\beta=0.501$, $\mathrm{t}=6.549, \mathrm{p}<0.001)$ and learning activities at $(\beta=0.678$, $\mathrm{t}=21.657, \mathrm{p}<0.001$ ). As a result, hypothesis $\mathrm{H} 1$ and $\mathrm{H} 2$ are 
supported. Further from the analysis, it shows that communicate for sharing was positively and significantly related to learning activities at $(\beta=0.566, \mathrm{t}=12.197, \mathrm{p}<$ 0.001). This indicates that hypothesis H3 is supported. Moreover, the analysis shows that learning activities is influenced directly by discussion for learning $(\beta=0.643$, $\mathrm{t}=21.168, \mathrm{p}<0.001)$ and content generating $(\beta=0.634$, $\mathrm{t}=20.182, \mathrm{p}<0.001$ ). As a result, hypothesis $\mathrm{H} 4$ and $\mathrm{H} 5$ are supported. In addition, the result shows learning activities was positively and significantly related to teaching and learning at $(\beta=0.182, \mathrm{t}=1.970, \mathrm{p}<0.001)$ and it shows that $\mathrm{H} 6$ is supported.
The results show all the relationships between 18 variables and items are supported. Details discussion is provided in this section. The results revealed that social media use is positively and significantly with 3 items with the t-value 27.247 to 7.767 . The results also show that learning activities is positively and significantly with 3 items with the t-value 33.257 to 10.235 . Further from the analysis, communicate for sharing is positively and significantly with 3 items with the t-value 51.217 to 45.789 . The results also show that discussion for learning variable is positively and significantly with 3 items with the t-value 53.436 to 12.900 . Content generating and teaching and learning are positively and significantly with 3 items were t-value 37.249 to 20.350 and 106.480 to 59.940 respectively.

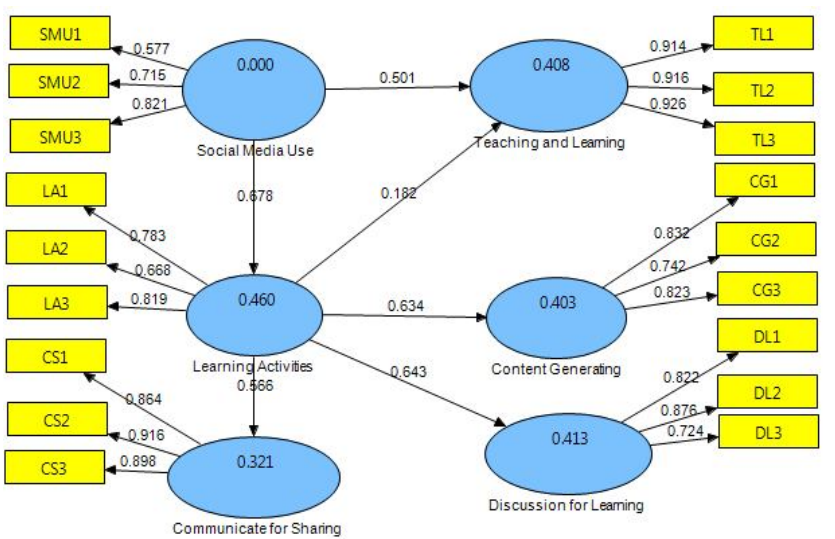

Figure 2: Path coefficients results

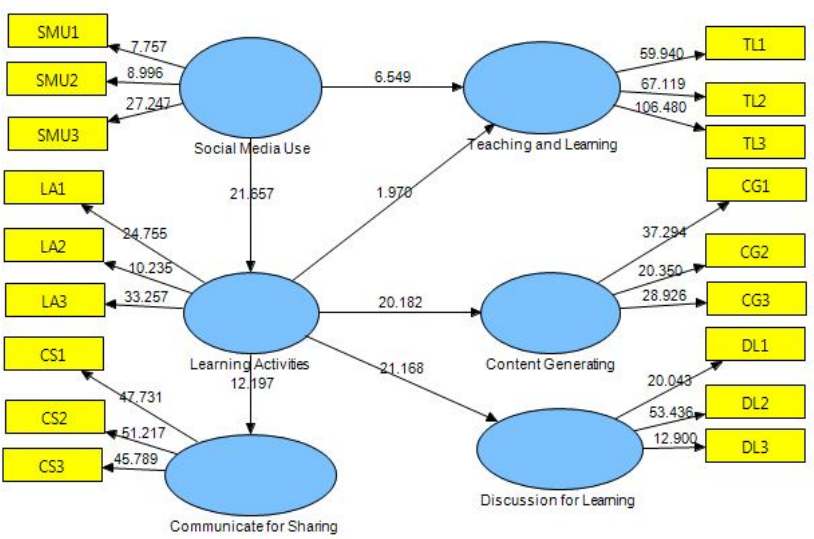

Figure 3: Path coefficients T values

Table 5: Hypotheses testing for variables

\begin{tabular}{cccccc}
\hline H & \multirow{2}{*}{ Relationship } & \multirow{2}{*}{ Path coefficient } & $\begin{array}{c}\text { Standard } \\
\text { Error }\end{array}$ & $\begin{array}{c}\text { Talue } \\
\text { Result }\end{array}$ & Supported \\
\hline H1 & SMU $\rightarrow$ TL & 0.501 & 0.047 & 6.549 & Su \\
H2 & SMU $\rightarrow$ LA & 0.678 & 0.032 & 21.65 & Supported \\
& & & & 7 & \\
H3 & CS $\rightarrow$ LA & 0.566 & 0.44 & $\begin{array}{c}12.19 \\
7\end{array}$ & Supported \\
H4 & DL $\rightarrow$ LA & 0.643 & 0.57 & 21.16 & Supported \\
& & & & 8 & \\
H5 & CG $\rightarrow$ LA & 0.634 & 0.51 & 20.18 & Supported \\
& & & & 2 & Supported \\
\hline
\end{tabular}

Table 6 shows the relationship between variables and items.

Table 4: Discriminant validity

\begin{tabular}{ccccccc}
\hline Variables & SMU & LA & CS & DL & CG & TL \\
\hline Social Media Use & $\mathbf{0 . 8 5}$ & & & & & \\
& $\mathbf{3}$ & & & & & \\
Learning Activities & 0.76 & $\mathbf{0 . 7 9}$ & & & & \\
Communicate for & 0.74 & 0.51 & $\mathbf{0 . 8 0}$ & & & \\
Sharing & 0 & 2 & $\mathbf{9}$ & & & \\
Discussion for & 0.54 & 0.61 & 0.70 & $\mathbf{0 . 7 3}$ & & \\
Learning & 7 & 8 & 2 & $\mathbf{9}$ & & \\
Content Generating & 0.69 & 0.53 & 0.60 & 0.59 & $\mathbf{0 . 8 1}$ & \\
& 7 & 9 & 4 & 4 & $\mathbf{7}$ & \\
Teaching and Learning & 0.70 & 0.67 & 0.45 & 0.61 & 0.71 & $\mathbf{0 . 8 8}$ \\
& 6 & 2 & 9 & 7 & 2 & $\mathbf{0}$ \\
\hline
\end{tabular}

\begin{tabular}{|c|c|c|c|c|c|c|}
\hline Variables & Code & $\begin{array}{c}\text { Factors } \\
\text { Loading }\end{array}$ & R-Square & $\begin{array}{l}\text { Cronbach's } \\
\text { Alpha }\end{array}$ & $\begin{array}{l}\text { Composite } \\
\text { Reliability }\end{array}$ & AVE \\
\hline \multirow{3}{*}{$\begin{array}{l}\text { Social Media } \\
\text { Use }\end{array}$} & SMU1 & 0.577 & \multirow{3}{*}{0.000} & \multirow{3}{*}{0.713} & \multirow{3}{*}{0.794} & \multirow{3}{*}{$\begin{array}{c}0.58 \\
4\end{array}$} \\
\hline & SMU2 & 0.715 & & & & \\
\hline & SMU3 & 0.821 & & & & \\
\hline \multirow{3}{*}{$\begin{array}{l}\text { Learning } \\
\text { Activities }\end{array}$} & LA1 & 0.783 & \multirow{3}{*}{0.460} & \multirow{3}{*}{0.821} & \multirow{3}{*}{0.872} & \multirow{3}{*}{$\begin{array}{c}0.59 \\
1\end{array}$} \\
\hline & LA2 & 0.668 & & & & \\
\hline & LA3 & 0.819 & & & & \\
\hline \multirow{2}{*}{$\begin{array}{l}\text { Communicate } \\
\text { for Sharing }\end{array}$} & CS1 & 0.884 & \multirow[b]{2}{*}{0.321} & \multirow[b]{2}{*}{0.901} & \multirow{2}{*}{0.903} & \multirow{2}{*}{$\begin{array}{c}0.69 \\
8\end{array}$} \\
\hline & $\begin{array}{l}\mathrm{CS} 2 \\
\mathrm{CS} 3\end{array}$ & 0.916 & & & & \\
\hline \multirow{3}{*}{$\begin{array}{l}\text { Discussion for } \\
\text { Learning }\end{array}$} & DL1 & 0.822 & \multirow{3}{*}{0.413} & \multirow{3}{*}{0.787} & \multirow{3}{*}{0.701} & \multirow{3}{*}{$\begin{array}{c}0.54 \\
7\end{array}$} \\
\hline & DL2 & 0.876 & & & & \\
\hline & DL3 & 0.724 & & & & \\
\hline \multirow{3}{*}{$\begin{array}{c}\text { Content } \\
\text { Generating }\end{array}$} & CG1 & 0.832 & \multirow{3}{*}{0.403} & \multirow{3}{*}{0.891} & \multirow{3}{*}{0.742} & \multirow{3}{*}{$\begin{array}{c}0.60 \\
1\end{array}$} \\
\hline & CG2 & 0.742 & & & & \\
\hline & CG3 & 0.823 & & & & \\
\hline \multirow{3}{*}{$\begin{array}{l}\text { Teaching and } \\
\text { Learning }\end{array}$} & TL1 & 0.914 & \multirow{3}{*}{0.408} & \multirow{3}{*}{0.917} & \multirow{3}{*}{0.897} & \multirow{3}{*}{$\begin{array}{c}0.70 \\
4\end{array}$} \\
\hline & TL2 & 0.916 & & & & \\
\hline & TL3 & 0.926 & & & & \\
\hline
\end{tabular}


Nur Shamsiah Abdul Rahman et al., International Journal of Advanced Trends in Computer Science and Engineering, 9(1.4), 2020,413 - 422

\begin{tabular}{|c|c|c|c|c|c|}
\hline $\mathrm{CS} \rightarrow \mathrm{CS} 2$ & 0.916 & 4.00 & 0.574 & $\begin{array}{c}51.21 \\
7\end{array}$ & 0.000 \\
\hline $\mathrm{CS} \rightarrow \mathrm{CS} 3$ & 0.898 & 4.09 & 0.485 & $\begin{array}{c}45.78 \\
9\end{array}$ & 0.000 \\
\hline $\mathrm{DL} \rightarrow \mathrm{DL} 1$ & 0.822 & 3.80 & 0.665 & $\begin{array}{c}20.04 \\
3\end{array}$ & 0.000 \\
\hline $\mathrm{DL} \rightarrow \mathrm{DL} 2$ & 0.876 & 3.89 & 0.614 & $\begin{array}{c}53.43 \\
6\end{array}$ & 0.000 \\
\hline $\mathrm{DL} \rightarrow \mathrm{DL} 3$ & 0.724 & 3.77 & 0.627 & $\begin{array}{c}12.90 \\
0\end{array}$ & 0.000 \\
\hline $\mathrm{CG} \rightarrow \mathrm{CG} 1$ & 0.832 & 4.03 & 0.606 & $\begin{array}{c}37.29 \\
4\end{array}$ & 0.000 \\
\hline $\mathrm{CG} \rightarrow \mathrm{CG} 2$ & 0.742 & 4.08 & 0.437 & $\begin{array}{c}20.35 \\
0\end{array}$ & 0.000 \\
\hline $\mathrm{CG} \rightarrow \mathrm{CG} 3$ & 0.823 & 3.89 & 0.610 & $\begin{array}{c}28.92 \\
6\end{array}$ & 0.000 \\
\hline $\mathrm{Tl} \rightarrow \mathrm{TL} 1$ & 0.914 & 3.91 & 0.640 & $\begin{array}{c}59.94 \\
0\end{array}$ & 0.000 \\
\hline $\mathrm{Tl} \rightarrow \mathrm{TL} 2$ & 0.916 & 3.92 & 0.761 & $\begin{array}{c}67.11 \\
9\end{array}$ & 0.000 \\
\hline $\mathrm{Tl} \rightarrow \mathrm{TL} 3$ & 0.926 & 3.88 & 0.777 & $\begin{array}{c}106.4 \\
8 \\
\end{array}$ & 0.000 \\
\hline
\end{tabular}

\section{CONCLUSION AND FUTURE WORK}

This paper discusses the use of social media for teaching and learning among students and explore the learning activities which affect teaching and learning. In response to the research question, the findings offer a detailed explanation of how the three learning activities namely content generating, communicate for sharing and discussion for learning have a positive significant to the teaching and learning. As the result, the present study supported the contention that social media use is effective both learning activities and teaching and learning. The result also showed that content generating; communicate for sharing and discussion for learning have a positive relationship with the learning activities. This result is in line with Hamid et al. [26] which stated that educational activities among students and lecturers can perform using social technologies includes but are not limited to the content generating, sharing, interacting and collaboratively socializing. The result will be beneficial for other researchers seeking guidance to appropriate or adapted the social media technologies for the teaching and learning purposes. Overall, as a result of these findings, all hypotheses are confirmed, which agree with the results of several past studies [5, 63, 64 and 65] but contradict the findings of past studies that suggested that the frequent use of social media harms academic performance [66].

The results of this study supported the contention that social media use is effective both learning activities and teaching and learning. The present study's results led the researchers to conclude that the model well represents the data collected based on its goodness-of-fit. The findings revealed all the six hypotheses proposed in this study are supported. The findings revealed the social media learning technologies has become commonplace in today's higher education and need to be appropriated or adapted to be used effectively in higher education for teaching and learning purposes since the social media not originally designed for the educational purposes. For future studies, it is recommended that authors can include other factors that align with the educational needs and in order to have more sound result, the developed scale should be applied to wider groups. Moreover, the subject can be examined in a more detailed way which takes the relationship between different demographic variables.

\section{ACKNOWLEDGEMENT}

This research was fully funded by Universiti Malaysia Pahang, grant number RDU1803147.

\section{REFERENCES}

1. A. Tulaboev and A. Oxley. A Case Study on Using Web 2.0 Social Networking Tools in Higher Education, in International Conference on Computer \& Information Science (ICCIS), 2012.

2. N. Li, S. El Helou and D. Gillet. Using social media for collaborative learning in higher education: a case study, in Proc. ACHI 2012, pp. 285-290, 2012.

3. I. Yakin. The Utilization of Social Media Tools for Informal Learning Activities: A Survey Study, Mevlana International Journal of Education (MIJE), Vol. 3(4), pp.108-117, 2013.

4. N. H. Mohd Alwi, N. Ahmad Mahir and S. Ismail. Infusing Social Media in Teaching and Learning (TnL) at Tertiary Institutions: A Case of Effective Communication in University Sains Islam Malaysia (USIM), Procedia- Social and Behavioral Sciences, Vol. 155, pp. 265-270, 2014.

5. W. Al-rahmi and M. Othman. The impact of social media use on academic performance among university students: A pilot study, Journal of Information Systems Research and Innovation, Vol. 4(12), pp. 1-9, 2013.

6. D. Eden, D. B. Tom, G. Peter and V. Martha. The ECAR National Study of Undergraduate Students and Information Technology, EDUCAUSE Center for Applied Research, 2011.

7. A. K. Alhazmi and A. A. Rahman. Why LMS failed to support student learning in higher education institutions, in E-Learning, E-Management and E-Services (IS3e), 2012 IEEE Symposium on 21-24 Oct. 2012, pp. 1-5, 2012.

https://doi.org/10.1109/IS3e.2012.6414943

8. S. Griffith and L. Liyanage. An Introduction to the potential of social networking sites in education, Emerging Technologies Conference 2008. University of Wollongong: Research Online, 2008.

9. R. Junco. The Relationship between frequency of Facebook use, participation in Facebook activities, and student engagement, Computers and Education, Vol. 58, pp. 162-171, 2012.

10. C. Mcloughlin and M. J. W. Lee. Personalized and self-regulated learning in the Web 2.0 era: 
International exemplars of innovative pedagogy using social software, Australasian Journal of Educational Technology, Vol. 26, pp. 28-43, 2010.

11. M. Thongmak. Facebook Adoption as Computer-Mediated Communication for University Students, in AMCIS 2011, pp. 31. 2011.

12. M. Masrom and S. Usat. Understanding Students' Behavior on the use of Online Social Networking, in Proceedings of the 4th International Conference on Computing and Informatics, Universiti Utara Malaysia, Malaysia, 2013.

13. R. Ratneswary and V. Rasiah. Transformative Higher Education Teaching and Learning: Using Social Media in a Team-Based Learning Environment, Procedia-Social and Behavioral Sciences, Vol. 123, pp. 369-379, 2013.

14. A. M. Elkaseh, K. W. Wong and C. C. Fung. Perceived Ease of use and perceived usefulness of social media for e-Learning in Libyan higher education: A structural equation modeling analysis, International Journal of Information and Education Technology, Vol. 6(3), 2014.

15. H. Bicen and $H$. Uzunboylu. The use of social networking sites in Education: A case study of Facebook, Journal of Universal Computer Science, Vol. 19(5), pp. 658-671, 2013.

16. A. Hamat, A. A. Embi and H. A. Hasan. The use of social networking sites among Malaysian University Students, International Education Studies, Vol. 5(3), 2012.

17. R. Ventura and J. M. Quero. Using Facebook in University Teaching: A Practical Case Study, Procedia - Social and Behavioral Sciences, Vol. 83, pp. 1032-1038, 2013.

18. N. S. Abdul Rahman, L. Handayani, M. S. Othman, W. M. Al-Rahmi, S. Kasim, T. Sutikno. Social media for collaborative learning, International Journal of Electrical and Computer Engineering, Vol. 10, pp. 1070-1078, 2020.

19. R. Junco, G. Heiberger and E. Loken. The effect of Twitter on college student engagement and grades, Journal of Computer Assisted Learning, Vol. 27(1), pp. 119-132, 2011.

20. L. M. Blaschke, S. Porto, and G. Kurtz. Assessing the added value of Web 2.0 tools for e-learning: the MDE experience', in Proceedings of the Sixth European Distance and E-learning Network (EDEN) Research Workshop. 2010 Budapest, Hungary. 25-27 October 2010.

21. B. Alexander. Web 2.0: A new wave of innovation for teaching and learning. EDUCAUSE Review.

22. C. L. Munoz and T. L. Towner. Opening Facebook: How to use Facebook in the college classroom, In Proceedings of Society for Information Technology and Teacher Education Conference, Charleston, South Carolina, pp. 2623-2627, 2009.
23. N. S. A. Rahman, A. N. Rosman and N. A. Sahabudin. Students' Continuance of Using E-Learning System: A Review of Conceptual Frameworks, IOP Conference Series: Materials Science and Engineering, Vol. 769, pp. $1-8,2020$.

24. M. Li and Z. Liu. The Role of Online Social Networks in Students' E-learning Experiences, International Conference on Computational Intelligence and Software Engineering (CiSE), pp. 1-4, 2009.

25. S. Hamid, J. Waycott, S. Chang and S. Kurnia. Appropriating Online Social Networking (OSN) Activities for Higher Education: Two Malaysian cases, in Proceedings ascilite Hobart 2011, pp. 526-538, 2011.

26. N. D. S. Chetty, L. Handayani, N. A. Sahabudin, Z. Ali, N. Hamzah, N. S. A. Rahman, S. Kasim. Learning styles and teaching styles determine students' academic performances, International Journal of Evaluation and Research in Education, Vol. 8, pp. 610-615, 2019. https://doi.org/10.11591/ijere.v8i4.20345

27. K. A. Meyer. Web 2.0 research: Introduction to the special issue, Internet and Higher Education, Vol. 1(3)4, pp. 177-178, 2010.

28. W. M. Al-Rahmi, N. Alias, M. S. Othman, A. I. Alzahrani, O. Alfarraj, A. A. Saged, N. S. A. Rahman. Use of e-learning by University students in Malaysian higher educational institutions: A case in Universiti Teknologi Malaysia, IEEE Access, Vol. 6, pp. 14268-14276, 2018.

29. P. Racthman, and D. Firpo. Using social networking technology to enhance learning in higher education: A case study using Facebook, in 44th Hawaii International Conference on Systems Science Hawaii, USA, 2011.

30. H. R. Chen, J. P. Hwang, T. T. Wu, Y. M. Huang and H. T. Hsueh. Assessment of implementing a digital game-based learning system over Facebook, in 11th IEEE International Conference on Advanced Learning Technologies, Athens, GA, 2011.

31. M. I. Hosny, and S. Fatima. Facebook in education: Students, teachers, and library perspectives, Journal of Computing, Vol. 4(6), pp. 78-86, 2012.

32. Y-W. Liao, Y-M. Huang, H-C. Chen and S-H Huang. Exploring the antecedents of collaborative learning performance over social networking sites in a ubiquitous learning context, Computers in Human Behavior, Vol. 43, pp. 313-323, 2015.

33. R. Klamma, M. A. Chatti, E. Duval, H. Hummel, Hvannberg, E. T. Kravcik, M. Law, E. Naeve, A. and P. Scott. Social software for life-long learning, Educational Technology \& Society, Vol. 10 (3), pp. 72-83, 2007.

34. C. Greenhow and E. Robelia. Informal learning and identity formation in online social networks, Learning, Media and Technology, Vol. 34(2), pp. 119-140, 2009. 
35. J. Murphy and R. Lebans. Unexpected outcomes: Web 2.0 in the secondary school classroom, International Journal of Technology in Teaching and Learning, Vol. 4(2), pp. 134-147, 2008.

36. N. Selwyn. Screw blackboard...do it on Facebook!': An investigation of students' educational use of Facebook, Presented at the "Poke 1.0=Facebook Social research Symposium. University of London, 2007.

37. H. Ajjan and R. Hartshorne. Investigating faculty decisions to adopt web 2.0 technologies: Theory and empirical tests, Internet and Higher education, Vol. 11, pp. 71-80, 2008.

38. Z. Tasir, Al-Dheleai, Y. M. Harun, J. and Shukor, N. A. Students' perception towards the use of social networking as an E-Learning Platform, Recent Researches in Education, 2011.

39. O. Awodele, S. Idowu, O. Anjorin, A. Adedire and V. Akpore. University Enhancement System using a social networking approache: Extending E-Learning issues, Informing Science and Information Technology, Vol. 6, 2009.

40. S. G. Mazman and Y. K. Usluel. Modeling educational usage of Facebook, Computers \& Education, Vol. 55(2), pp. 444-453, 2010.

41. S. Wheelers, P. Yeomans and D. Wheeler. The good, the bad and the Wiki: Evaluating student-generated content for collaborative learning, British Journal of Educational Technology. Vol. 39(6), pp. 987-995, 2008.

42. S. Hamid, J. Waycott, S. Kurnia and S. Chang. Understanding students' perceptions of the benefits of online social networking use for teaching and learning, Internet and Higher Education, Vol. 26, pp. $1-9,2015$.

43. N. S. A. Rahman, N. S. W. Z. Adli, A. F. M. Raffei and N. S. N. Ismail. Factors Determination MOOCs Continuance Intention: A Proposed Conceptual Framework, IOP Conf. Series: Materials Science and Engineering, Vol.769, pp. 1-8, 2020.

44. S. Griffith and L. Liyanage. An Introduction to the Potential of Social Networking Sites in education, in Proceedings of the Second Emerging Technologies Conference, 2008.

45. G. Kennedy, B. Dalgarno, K. Gray, T. Judd, J. Waycott, and $\mathrm{S}$. Bennet. The Net Generation Are Not Big Users of Web 2.0 Technologies: Preliminary Findings, in Proceedings Ascilite Singapore 2007, Singapore. 2007.

46. L. Lockyer, and J. Patterson. Integrating Social Networking Technologies In Education: A Case Study Of A Formal Learning Environment, Eighth IEEE International Conference on Advanced Learning Technologies, 2008.

https://doi.org/10.1109/ICALT.2008.67

47. C. Murray. Schools and Social Networking: Fear or Education?, Synergy Perspectives: Local, Vol. 6(1), pp. 8-12, 2008.

48. E. Ras, and J. Rech. Using Wikis to Support the Net Generation in Improving Knowledge Acquisition in
Capstone Projects, The Journal of Systems and Software, Vol. 82, pp. 553-562, 2009.

49. J. Sandars and S. Schroter. Web 2.0 Technologies for Undergraduate and Postgraduate Medical Education: An Online Survey, Postgraduate Medical Journal. Vol. 83, pp. 759-762, 2007.

50. T. Coffin and J. Fournier. Social media in the learning setting: Opportunities and Challenges, Information Technology. University of Washington, 2015.

51. A. Hollyhead, D. J. Edwards and G. D. Holt. The use of virtual learning environment (VLE) and social network site (SNS) hosted forums in higher education: A preliminary examination, Industry and Higher Education. Vol. 26 (5), pp. 369-379, 2012.

52. J. Schroder, and T. Greenbowe. The chemistry of Facebook: using social networking to create an online community for the organic chemistry laboratory, Innovate: Journal of Online Education, Vol. 5(4), 2009.

53. A. Hemmi, S. Bayne, and R. Land. The appropriation and repurposing of social technologies in higher education, Journal of Assisted Learning, Vol. 25 (Special Issues), pp. 19-30, 2009.

54. M. H. Zakaria, J. Watson, and S. L. Edwards. Investigating the use of Web 2.0 technology by Malaysian students, Multicultural Education \& Technology Journal, Vol. 4(1), pp. 17-29, 2010.

55. M. K. Kabilan, N. Ahmad, and M. J. Zainol Abidin. Facebook: An online environment for learning of English in institutions of higher education?, Internet and Higher Education, Vol. 13, pp. 179-187, 2010.

56. G. Augustsson. Web 2.0, pedagogical support for reflexive and emotional social interaction among Sweedish students, The Internet and Higher Education, Vol. 13(4), pp. 197-205, 2010.

57. A. Schroder, S Minocha, and C. Schneider. The strengths, weaknesses, opportunities and threats of using social software in higher and further education teaching and learning, Journal of Computer Assisted Learning, Vol. 26(3), pp. 159-174, 2010

58. K. Gray, S, Chang, and G. Kennedy. Use of social web technologies by international and domestic undergraduate students: Implications for internationalizing learning and teaching in Australian universities, Technology Pedagogy and Education, Vol. 19(1), pp. 31-46, 2010.

59. K. Ala-Mutka. Learning in informal online networks and communities, Seville, Spain: Institute for Prospective Technological Studies, European Commision, 2010

60. C. Fornell, and D. F. Larcker. Evaluating structural equation models with unobservable variables and measurement error, Journal of Marketing Research, Vol. 39-50, 1981.

61. J. F. Hair, C. M. Ringle, and M. Sarstedt. PLS-SEM: Indeed a silver bullet, Journal of Marketing Theory and Practice, Vol. 18(2), pp. 139-152, 2010. 
62. M. Chow, D. K. Herold, T. M. Choo, and K. Chan. Extending the technology acceptance model to explore the intention to use Second Life for enhancing healthcare education, Computers \& Education, Vol. 59(4), pp. 1136-1144, 2012.

63. R.P. Bagozzi, F. D. Davis, and P. R. Warshaw. Extrinsic and intrinsic motivation to use computers in the workplace, Journal of Applied Social Psychology, Vol. 22(14), pp. 111-1132, 1992.

64. W. M. Al-rahmi, M. S. Othman, and L. M. Yusuf. Social Media for Collaborative Learning and Engagement: Adoption Framework in Higher Education Institutions in Malaysia, Mediterranean Journal of Social Sciences, Vol. 6(3 S1), pp. 246, 2015.

65. W. M. Al-rahmi, M. S. Othman, and L. M. Yusuf. Effect of Engagement and Collaborative Learning on Satisfaction Through the use of Social Media on Malaysian Higher Education, Research Journal of Applied Sciences, Engineering and Technology, Vol 9(12), pp. 1132-1142, 2015.

66. W. M. Al-rahmi, M. S. Othman, and L. M. Yusuf. The role of using social media for collaborative learning to improve academic performance of students and researchers in Malaysian higher education, The International Review of Research in Open and Distributed Learning, Vol. 16:(4), 2015.

67. J. Kirschner, F. Erkens, G. Kirschnker, and F. Paas. Making the black box of collaborative learning transparent: Combining process-oriented and cognitive load approaches, Educational Psychology Review, Vol. 22, pp. 139-154, 2010.

https://doi.org/10.1007/s10648-010-9131-x 